Research article

\title{
The burn severity and plant recovery relationship affect the biological and chemical soil properties of Pinus halepensis Mill. stands in the short and mid- terms after wildfire
}

\author{
D. Moya ${ }^{\mathrm{a}, *}$, S. González-De Vega ${ }^{\mathrm{a}}$, E. Lozano ${ }^{\mathrm{b}}$, F. García-Orenes ${ }^{\mathrm{b}}$, J. Mataix-Solera ${ }^{\mathrm{b}}$, \\ M.E. Lucas-Borja ${ }^{\mathrm{a}}$, J. de las Heras ${ }^{\mathrm{a}}$ \\ ${ }^{a}$ Escuela Técnica Superior Ingenieros Agrónomos y Montes, Universidad de Castilla-La Mancha, Campus Universitario, 02071, Albacete, Spain \\ ${ }^{\mathrm{b}}$ GEA (Grupo de Edafología Ambiental), Environmental Soil Science Group, Department of Agrochemistry and Environment, Universidad Miguel Hernández, Avda. De la \\ Universidad $s / n, 03202$, Elche, Spain
}

A R T I C L E I N F O

\section{Keywords:}

Ecosystem response

Soil biology

Enzymatic activity

Post-fire management

\begin{abstract}
A B S T R A C T
In the Mediterranean Basin, changes in climate and fire regime (increased recurrence and severity) reduce ecosystem services after wildfires by increasing soil degradation and losses in plant diversity. Our study was a biological approach to relate soil properties to vegetation recovery and burn severity. We focused our study on the natural recovery of the soil-plant interphase in Pinus halepensis Mill. forests located in the SE of Iberian Peninsula, a semiarid climate. We included some chemical properties 3 years after fire (available phosphorus (P) and soil organic carbon (Corg), among others), and biological soil indicators 3 and 5 years after fire (i.e. basal soil respiration (BSR), microbial biomass carbon (Cmic), carbon mineralization coefficient (Cmineral), metabolic quotient $\left(\mathrm{qCO}_{2}\right)$ and microbial quotient (Cmic:Corg)). We analyzed the activity of three different enzymes: urease (UR), phosphatase (PHP) and $\beta$-glucosidase (GLU).

The changes in most chemical properties were ephemeral, but $\mathrm{P}$ and Corg showed higher values in burned areas, and the highest were found for low-moderate severity. Plant recovery was the triggering factor for the recovery of Corg and biological soil function. Burn severity and time after fire influenced Cmic and the Cmic:Corg, which were higher for moderate-high severity 3 years later, but were below the unburned values 5 years after fire. The microbial activities of GLU and UR were recovered in burned areas 5 years after fire. The PHP values lowered according to higher burn severity and time after fire. The soil ecological trends obtained by a principal component analysis revealed a relationship linking GLU, BSR and $\mathrm{qCO}_{2}$ that explained soil response to burn severity. PHP, Cmic and Cmic:Corg explained most of the variability related to time after fire.

Our results provide insights into how burn severity, in Mediterranean fire-prone Aleppo pine stands, modulated the natural plant recovery linked to soil biochemical and microbiological response to fire. High burn severity limited natural vegetation recovery, and both reduced biological soil functionality. This knowledge can be implemented in post-fire planning to apply post-fire management (for mitigation and restoration) in which the "no intervention" tool should be contemplated. These findings provide information to be applied in adaptive forest management to improve the resilience of vulnerable ecosystems and to reduce burn severity in future fire events.
\end{abstract}

\section{Introduction}

Forest fires are an important ecological factor in ecosystem evolution and adaption, and play a key role in the Mediterranean Region (Trabaud, 2000) by shaping plant traits (Keeley et al., 2012). Fire regime affects post-fire ecosystem evolution and resilience (Bond and Keeley, 2005), but changes in climate and land use induce alterations in the Mediterranean Basin (San-Miguel-Ayanz et al., 2012; Santana et al., 2014). Increased fire frequency reduces ecosystem resilience and its ability to recover to a pre-disturbance state (Diaz-Delgado et al., 2003), which reduces the diversity and abundance of species (Eugenio and Lloret, 2004; Tessler et al., 2016).

The main factors that influence post-fire secondary succession are: species composition (according to the initial floristic model (Egler,

\footnotetext{
${ }^{*}$ Corresponding author.

E-mail address: Daniel.Moya@uclm.es (D. Moya).
} 
1954)), burn severity (Keeley, 2009), the season when fire occurs (Liu, 2016), and the existence of a soil seed bank capable of surviving disturbance (Moya et al., 2008). Post-fire plant regeneration also depends on adaptive traits and fire damage (Pausas and Keeley, 2014). For proper post-fire management, burn severity identification is needed to understand the effects of fire and the associated environmental processes (Úbeda and Outeiro, 2009). This knowledge may be used to implement post-fire actions according to fire damage related to soil, the water system, flora, fauna, the atmosphere and human society (DeBano et al., 1998; Bento-Gonçalves et al., 2012). Post-fire plant-soil interphase monitoring is a key point to consider in adaptive forest management, mainly in climate change scenarios as they influence fire regimes and ecosystem productivity (Doblas-Miranda et al., 2017).

The loss of ecosystem services from severe wildfires is linked to changes in soil biota, which can be evaluated recording the activity of soil microorganisms (Morugán-Coronado et al., 2015). The soil in Mediterranean forests is especially sensitive to wildfire as its biological soil stability is vulnerable, especially in unmanaged forests located in arid regions (Hedo et al., 2015). Burn severity has been described as the most critical factor that directly affects the plant community, soil characteristics and microbial activity (González-De Vega et al., 2016; Maia et al., 2012; Vega et al., 2013). The recovery of the soil-plant interphase should be monitored after stabilizing and restoring disturbed ecosystems if enhancing their resilience is one of the main objectives (Certini, 2005; Doblas-Miranda et al., 2015). The enzymatic activity of soil provides information relating the soil microbial community and its variations (Bárcenas-Moreno et al., 2016). The latter has been used to evaluate the effect of heat on plant community, soil microorganisms, soil properties and their interrelationships (López-Poma and Bautista, 2014). In burned Pinus halepensis Mill. (Aleppo pine) forests, the soil microbial community varies in accordance with plant community and burn severity (López-Poma and Bautista, 2014; Hinojosa et al., 2016), which can be employed as a useful tool to promote soil recovery; i.e. the belowground microbial community structure and function by revegetation to reduce the negative impacts of high-burn severity events (Knelman et al., 2015). P. halepensis is the most widely distributed tree species throughout low-altitude forests in the Mediterranean Basin (Quezel, 2000), whose plant community is adapted to summer droughts and exaptated to wildfires (Keeley et al., 2012). The resilient plant communities that occur in Aleppo pine forests with a semiarid climate usually recover rapidly, but also heterogeneously given the spatial variability created by burn severity (Broncano and Retana, 2004; González-De Vega et al., 2016).

Our main study aim was to characterize the short- and mid-term effects of burn severity and plant recovery on the biological soil functionality of an Aleppo pine forest. The study was designed as a diachronic approach by monitoring the same field plots showing two burn severities twice (plus unburned) and if they displayed successful plant regeneration, or not. The initial hypothesis was that the negative effects on biological soil properties would be stronger and more persistent in the areas that had undergone high burn-severity, but would be attenuated if natural vegetation regeneration was successful. We recorded changes in soil biology linked to burn severity and forest recovery. The results and conclusions can be used to apply tools in adaptive forest management post-fire planning and decision making to reduce vulnerability to fire, stabilize sustainable fire regimes, or to rehabilitate and restore burned areas according to fire damage.

\section{Methods}

\subsection{Study area}

A wildfire (1-6 July 2012) burned almost 6500 ha in "Sierra de los Donceles" near Hellín in the south-eastern area of the province of Albacete (ignition point: $608309 \mathrm{E}, 4254211 \mathrm{~N}$; ETRS89 UTM 30N) (Fig. 1). The area remained unburned for at least 80 years, according to the information provided by the Forest Services of the Regional Government of Castilla-La Mancha and supported by the digital cartography obtained in the IGN (Spanish Geographic Institute).

It is a semiarid Mediterranean climate, according to the KöppenGeiger classification (Kottek et al., 2006) BSk is located on the upper meso-Mediterranean bioclimatic belt. The dry period occurs from June to September (relative humidity $<50 \%$ ). According to the averaging data from 1990 to 2014 (provided by the Spanish Meteorological Agency), the annual precipitation and temperature are $278.50 \mathrm{~mm}$ and $15.85^{\circ} \mathrm{C}$, respectively, although annual rainfall was slightly higher from 2012 to 2017 (García-Morote et al., 2017).

The soils at the site (Table 1 ) are classified as Aridisols (Lithic Haplocalcids), soils with long periods ( $>90$ days) and no water available for plants (Soil Survey Staff, 2014). The predominant landform is composed of dolomitic limestones, which shape strong rocky slopes with altitudes ranging from 500 to $700 \mathrm{~m}$ a.s.l.

The vegetation series at the site belonged to Rhamno lycioidisQuerceto cocciferae sigmetum (Rivas Martinez, 1982). The main tree species was Pinus halepensis Mill. (Aleppo pine). The serial scrub species and steppic grasslands were Macrochloa tenacissima (L) Kunth (Alpha grass), Quercus coccifera L. (Kermes oak) and Pistacia lentiscus L. (Mastic tree).

\subsection{Fire mapping and sampling plots}

The fire perimeter was provided by the Regional Government of Castilla-La Mancha. Study site and burn severity were evaluated by remote sensing and digital cartography, and using Digital Terrain Models (available from the Geographic Information National Centre; pixel size of $5 \mathrm{~m}$, matrix ASCII file format, geodesic reference system ETRS89) and orthophotos (available from the Geographic Information National Centre -National Aviation Plan Orthophotography mosaics; ECW format, geodetic reference system ETRS89). Images from the Landsat 7 Enhanced Thematic Mapper Plus (ETM +) data were used to calculate the delta-normalized burn ratio (dNBR) and to compose a burn severity map (Miller and Thode, 2007) with GIS software (QGIS, GNU General Public License, June 1991, 2.8.2-Wien).

Following the Spanish technical guide to manage burned forests (Alloza et al., 2014), the study was conducted after establishing a systematic grid measuring $500 \times 500 \mathrm{~m}$, which overlapped the fire perimeter. Located on grid nodes, the centre of the circular sampling plots (5-m radius; $78.5 \mathrm{~m}^{2}$ ) was set with a Monterra GPS receiver (Garmin International, Inc., Olathe, KS, USA).

To validate and improve the burn severity values obtained from the dNBR map (Gómez-Sánchez et al., 2017), we followed the semi-quantitative method proposed by Ryan et al. (1985), and improved in Alloza et al. (2014) and Vega et al. (2013), similarly to the composite burn index (CBI; Key et al., 2006). In spring 2013, we sampled and characterized burn severity for vegetation (amount of green, charred and scorched vegetation in trees, shrubs and herbaceous strata) and soil (ash colour, biological soil crusts, soil horizon affection and bare soil). Two burn severity categories were defined, low-medium severity (L-M) and medium-high severity (M-H), including unburned areas (UB) as the control and mature plots (Fig. 1).

The vegetation before and after fire located in the grid nodes was characterized by digital cartography according to the main vegetation types defined by González-De Vega et al. (2016), and was validated by field sampling (pre-fire vegetation validated by visiting the remaining unburned areas). The Geographic Information National Centre (the Spanish National Plan for Aerial Orthophotography) provided the aerial images in a geometrically rectified ECW format (from the geodetic reference system ETRS89), which were recorded the spring before (2012) and after the wildfire (2015 and 2017). The pre- and post-fire vegetation types were compared to characterize plant recovery as regenerated (REG) or unregenerated plots (UNREG). To prevent biased vegetation type, which may affect soil microbiology, we selected three REG and 

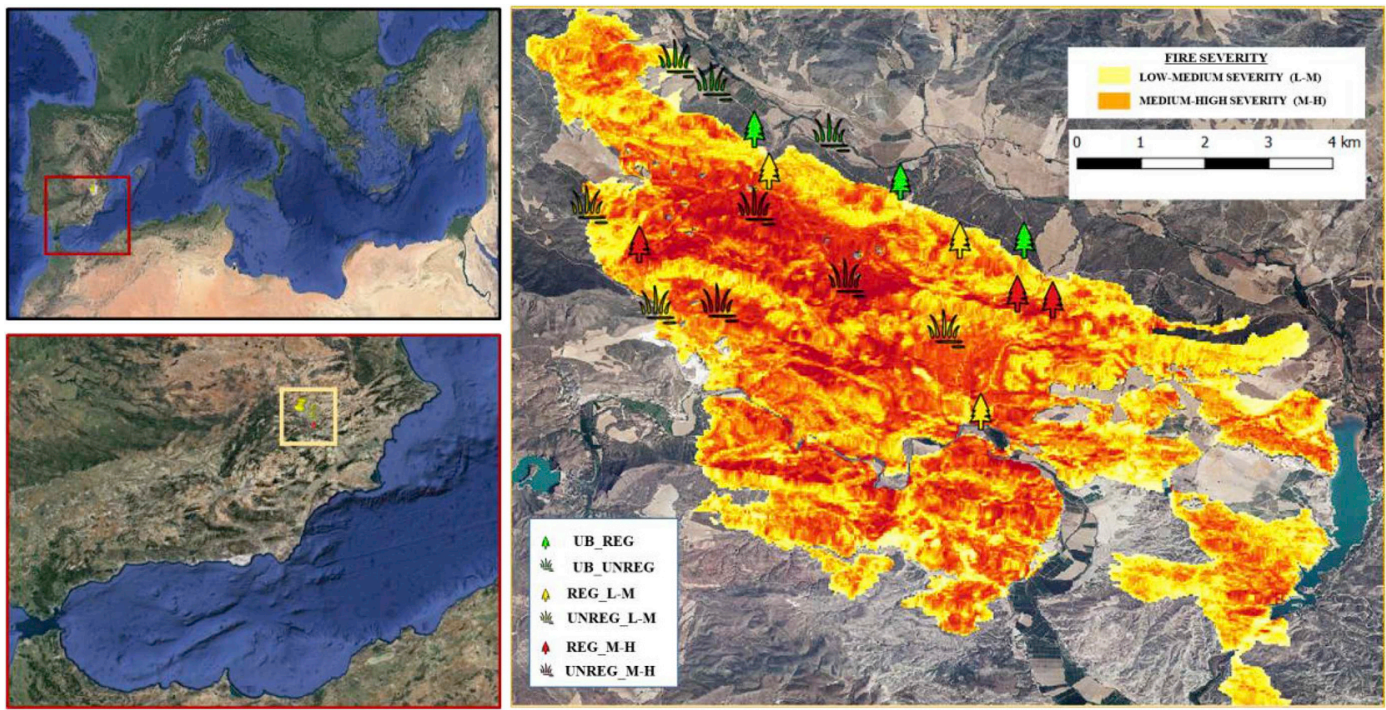

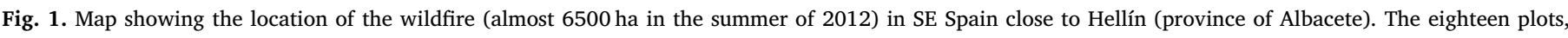

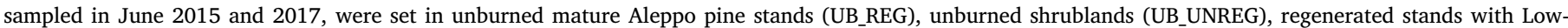

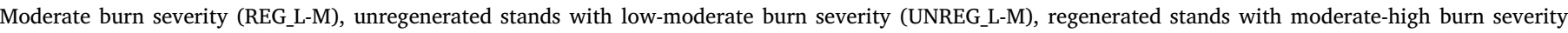
(REG_M-H), unregenerated stands with moderate-high burn severity (UNREG_M-H).

Table 1

Mean ( \pm SE) soil characteristics $(0-5 \mathrm{~cm}$ depth) in the study area 3 years after fire (June 2015, $\mathrm{n}=16$ (6 samples for an unburned and 12 for a burned area).

\begin{tabular}{lll}
\hline Soil Parameter & Unburned & Burned \\
\hline Sand (\%) & $54.67 \pm 2.03$ & $53.50 \pm 1.17$ \\
Silt (\%) & $14.58 \pm 0.38$ & $13.50 \pm 0.39$ \\
Clay (\%) & $31.53 \pm 0.57$ & $32.99 \pm 0.96$ \\
pH (1:2.5) & $8.10 \pm 0.02$ & $8.10 \pm 0.03$ \\
Organic matter (\%) & $6.17 \pm 1.98$ & $5.98 \pm 0.98$ \\
C/N & $13.38 \pm 0.26$ & $13.92 \pm 0.30$ \\
Total C (\%) & $3.52 \pm 0.68$ & $3.79 \pm 0.37$ \\
Total nitrogen (\%) & $0.27 \pm 0.01$ & $0.28 \pm 0.02$ \\
Available phosphorus (ppm) & $3.25 \pm 0.85$ & $12.00 \pm 3.56$ \\
\hline
\end{tabular}

three UNREG plots from the two dominant vegetation types (Aleppo pine forests (canopy cover fraction $>30 \%$ ) or defined GrasslandShrublands) in both the burned and unburned areas (Gonzalez-De Vega et al., 2018). Vegetation was characterized as REG if the dominant vegetation type remained after fire (recovered with similar cover and diversity), and as UNREG if the dominant vegetation type reached a degraded successional stage after fire (the Aleppo pine forest to shrublands, shrublands to grasslands, or bare soil percentages increased to more than $50 \%$ ).

\subsection{Soil sampling and analysis}

According to our experimental design, 36 soil samples were collected; i.e. 3 plots (replicates) *3 burn severity classes*2 plant recovery types*2 years (June 2015 and 2017) (Fig. 1). Each soil sample was composed of six soil subsamples $(2 \times 2 \mathrm{~m}$ subplots), including the upper $5 \mathrm{~cm}$ layer prior to litter removal, in the plots with a similar orientation, slope and percentage of bare soil to reduce the variability of other factors. Soil subsamples were mixed in a bag, the plants and debris removed, and taken to the laboratory where they were passed through a 2 -mm sieve and kept at $4{ }^{\circ} \mathrm{C}$ for less than 1 month to avoid any influence on the parameters analyzed in the laboratory (Andrés Abellan et al., 2011; Bárcenas-Moreno et al., 2016).

The physico-chemical characterization was based on a soil analysis done in 2015 (3 years after fire) to record texture, $\mathrm{pH}$, Kjeldahl nitrogen (N) (Bremmer and Mulvaney, 1982), available phosphorus (P) (Olsen and Sommers, 1982) and soil organic carbon (Corg), as determined by the potassium dichromate oxidation method (Nelson and Sommers, 1982) (Table 1).

Our biological approach was based on the response of the soil quality indicators, which have been shown to be sensitive to soil burning (Mataix-Solera et al., 2009; Moya et al., 2018), including basal soil respiration (BSR), microbial biomass carbon (Cmic), the carbon mineralization coefficient (Cmineral) (1), the metabolic quotient $\left(\mathrm{qCO}_{2}\right)$ (2), the microbial quotient (Cmic:Corg) (3), and three enzymatic activities. BSR was measured in a multiple sensor respirometer (Micro-Oxymax, Columbus, OH, USA). Following the method adapted by Bárcenas-Moreno et al. (2016), Cmic was determined by the fumigation-extraction method (Vance et al., 1987).

Cmineral $=\frac{\text { Basal Soil Respiration }(B S R)}{\text { Soil organic Carbon }(\text { Corg })}$

$q \mathrm{CO}_{2}=\frac{\text { Basal Soil Respiration }(B S R)}{\text { Microbial biomass Carbon (Cmic) }}$

Cmic: Corg $=\frac{\text { Microbial biomass Carbon }(\text { Cmic) }}{\text { Soil organic Carbon }(\text { Corg })}$

The activities of the three main enzymes were selected: urease (UR), phosphatase (PHP) and $\beta$-glucosidase (GLU). UR was assayed by taking urea as the substrate (Tabatabai, 1994). PHP and GLU were established using p-nitrophenyl phosphate disodium (PNPP, 0.115 M) and p-nitrophenyl- $\beta$-D-glucopyranoside (PNG, $0.05 \mathrm{M}$ ) as substrates, respectively (Tabatabai, 1994).

\subsection{Statistical analysis}

Three analyses were run to determine the relationship that linked biological soil variables with two categorical factors (burn severity (SEVERITY) and plant recovery (PLANTRECOV)), a numerical factor (time after fire (YEAR)) and their interactions. If the normality and homoscedasticity assumptions were not met, a square root transformation was applied to fit normal distribution. Multivariate statistical method (correlation analysis) analyses were performed by Pearson's method. To meet the statistical test assumptions (equality of variance and normal distribution), variables were square root-transformed whenever necessary. 
A one-way analysis of variance (ANOVA) or a factorial multivariate analysis of variance (MANOVA) was used to evaluate the effects of the significant factors, including YEAR as paired samples. The applied post hoc test was Fisher's Least Significant Difference (LSD test) with a critical p-value of 0.05 . To examine the non-correlated variables, the relationships among the numerical variables were tested by nonparametric Spearman Rank Correlation and Kruskal-Wallis tests instead of ANOVA. Boxplots were employed to examine the relationships between the numerical and categorical variables.

A principal component analysis (PCA, varimax normalized) was performed as a multivariate approach including the biological soil variables. The results were summarized in an ordination diagram to calculate the structure of dependence and correlation. The missing values were estimated to be covariance list-wise (based on complete cases) by creating a standardized correlation matrix. The PCA reduced the used variables by employing their linear combinations and accounted for most of the variability contained in the original data. The described statistical analyses were done with Statgraphics Centurion v. 18.1.03 (Statgraphics Technologies, Inc.), XLSTAT v. 2018 (Addinsoft) and the R software v. 3.2.1 (R Development Core Team).

\section{Results}

Burn severity induced no significant changes in the texture, $\mathrm{pH}$ or $\mathrm{N}$ recorded 3 years after fire. However, $\mathrm{P}$ and Corg were affected by the YEAR*SEVERITY interaction, in addition to the significant influence of PLANTRECOV on Corg (Fig. 2). P was higher in the burned areas, with a maximum value in L-M (17.75 $\pm 6.06 \mathrm{ppm})$ (Fig. 2a). Corg showed no significant differences between UB and L-M, but the values found in plots M-H were significantly lower $\left(4.82 \pm 1.02 \mathrm{~g} \mathrm{~kg}^{-1}\right)$ (Fig. 2b). The amount of Corg was higher in REG than in UNREG (8.25 \pm 1.07 and $3.83 \pm 0.53 \mathrm{~g} \mathrm{~kg}^{-1}$, respectively) (Fig. 2c).

Biological indicators BSR and Cmineral showed no significant differences in relation to the studied factors (YEAR, SEVERITY or PLANTRECOVERY), but gave total averaged values of $2.16 \pm 0.25 \mathrm{mg} \mathrm{CO}_{2}-\mathrm{C}$ $\mathrm{kg}^{-1}$ soil per $\mathrm{h}$ and $0.74 \pm 0.13 \mathrm{mg} \mathrm{C}^{-\mathrm{CO}_{2} \mathrm{~g}^{-1} \mathrm{Corg} \mathrm{h}} \mathrm{h}^{-1}$, respectively. We found that $\mathrm{Cmic}$ and Cmic:Corg were linked to the YEAR*SEVERITY interaction (Fig. 3). Three years after fire, Cmic was higher in $\mathrm{M}-\mathrm{H}$ than UB and L-M, but the Cmic values in the burned areas lowered 5 years after five (Fig. 3a). Cmic:Corg showed no differences only 3 years after fire, but these values were lower in the burned area 2 years later (Fig. 3b).

The three enzymatic activities were linked to the YEAR*SEVERITY interaction (Fig. 4). GLU showed increasing changes according to time after fire, but no significant changes were related to burn severity (Fig. 4a). UR also showed changes in the unburned plots depending on time after fire, but the burned plots had significantly lower values than the unburned ones (Fig. 4b). The PHP values were not related to YEAR, but were lower in the burned plots and lowered according to time after fire (Fig. 4c).

The Spearman rank correlations showed a negative significant correlation between factor SEV with PHP $(-0.40$, P-value $=0.03)$, while a significant positive correlation was obtained for YEAR with GLU $(0.84$, $\mathrm{P}$-value $<0.01)$ and UR $(0.42$, P-value $=0.02)$, which was negative for the associations between YEAR with PHP $(-0.46$, P-value $=0.01)$. UR and GLU increased according to time after fire. UR went from $0.86 \pm 0.09$ to $1.26 \pm 0.12 \mu \mathrm{mol} \mathrm{N_{4 }}{ }^{+} \mathrm{g}^{-1} \mathrm{~h}^{-1}$ and GLU from $0.48 \pm 0.02$ to $1.29 \pm 0.09 \mu \mathrm{mol} \mathrm{PNP} \mathrm{g}{ }^{-1} \mathrm{~h}^{-1}$ (3-5 years, respectively). PHP lowered as its values went from $2.12 \pm 0.23$ to $1.26 \pm 0.13 \mu \mathrm{mol} \mathrm{PNP} \mathrm{g}{ }^{-1} \mathrm{~h}^{-1}$ (3-5 years, respectively).

The PCA reduced the variables to a three-component solution (eigenvalues $>1$ ), which we simplified it to a two-component one (Fig. 5). The first component (PCA1) accounted for $39.21 \%$ of variability, while the second explained $22.86 \%$ of variability (PCA2). In all, two components accumulated $62.07 \%$ of the variability contained in the original data. The responses in soil microbiology related to burn
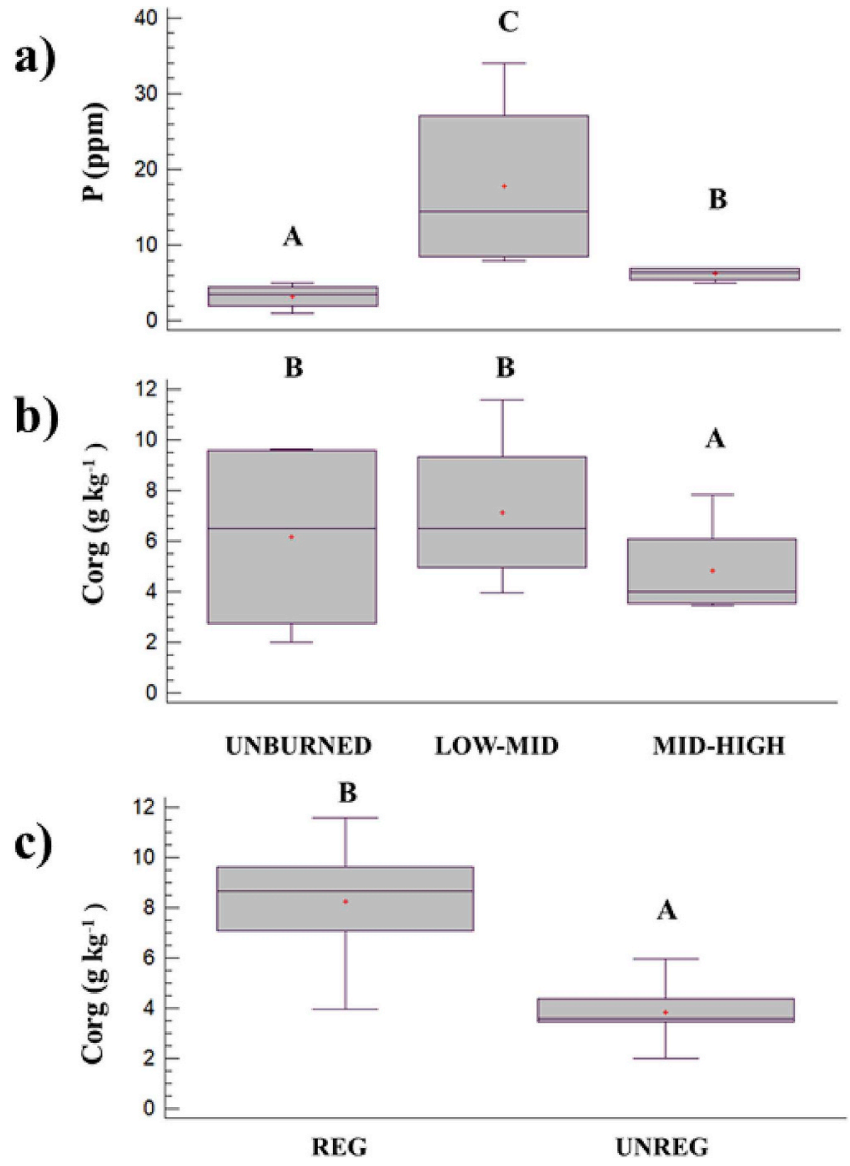

Fig. 2. Significant differences in soil recorded 3 years after fire depending on burn severity (unburned, low-moderate (LOW-MID) and moderate-high burn severity (MID-HIGH)) and natural vegetation recovery (successfully regenerated (REG) or degraded (UNREG)). a) P (available phosphorus, ppm) related to burn severity; b) Corg (soil organic carbon, $\mathrm{g} \mathrm{kg}^{-1}$ ) related to burn severity; c) Corg (soil organic carbon, $\mathrm{g} \mathrm{kg}^{-1}$ ) related to plant recovery. Different letters indicate significant differences between the means of groups (Fisher's Least Significant Difference (LSD) test).

severity clearly clustered along the PCA1 axis, whereas recovery according to time after fire was linked to the PCA2 axis. The squared cosine values that related variables to the soil response to burn severity (PCA1) were GLU (0.430), BSR (0.639) and $\mathrm{qCO}_{2}$ (0.774), which contributed $13.70 \%, 20.36 \%$ and $24.67 \%$ to explain variability, respectively. The squared cosine values to soil response to time after fire (PCA2) were PHP (0.377), Cmic (0.448) and Cmic:Corg (0.499), and contributed to variability by $18.73 \%, 24.48 \%$ and $27.32 \%$, respectively.

\section{Discussion}

Knowledge about the effects of burn severity on the plant-soil system (above and belowground impacts) is a major issue required to manage natural and semi-natural landscapes for ecosystem conservation purposes (Moreira et al., 2012). Wildfires can dramatically affect soil properties and nutrient cycling, but the proper restoration of a plant community and post-fire rehabilitation can stabilize and mitigate negative effects (Mataix-Solera et al., 2011).

Our short and mid-term post-fire results provided data about biological soil quality recovery patterns by distinguishing between either effect related to burn severity and plant recovery. Some effects were interlinked, or even triggered, but they need to be studied in-depth in different scenarios, such as plant communities (Moya et al., 2015), soil types (Soler and Úbeda, 2018) or in-depth soil damage (Zavala et al., 2014). The biological soil quality monitoring indicated both a positive 


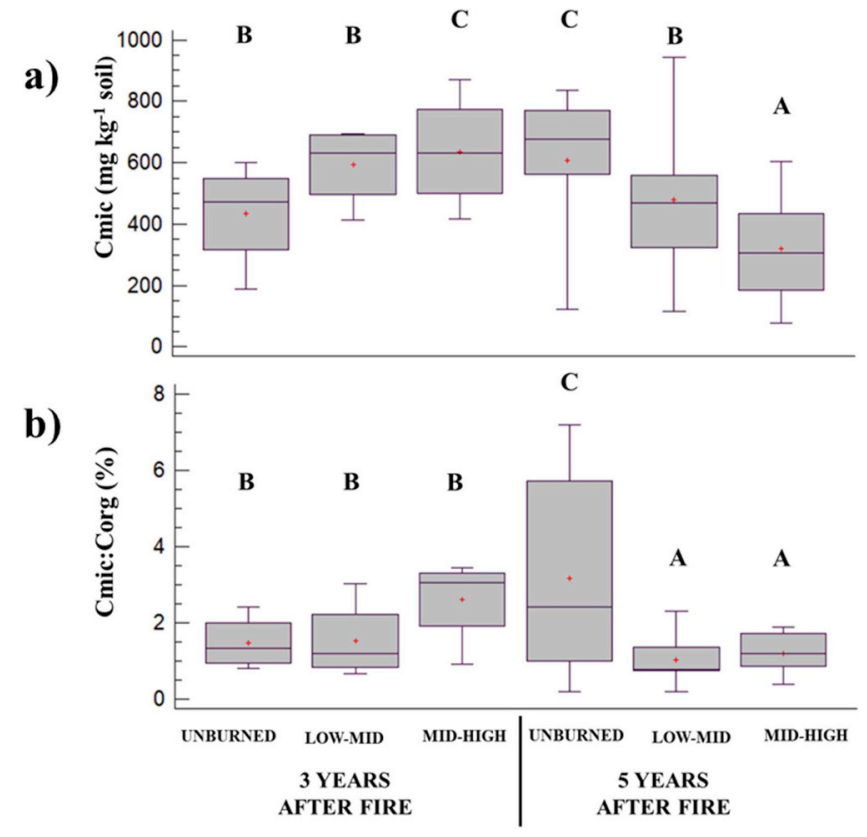

Fig. 3. Significant differences in the post-fire values of the biological soil indicators ( 3 and 5 years after), depending on burn severity (unburned, lowmoderate (LOW-MID) and moderate-high burn severity (MID-HIGH)). a) Cmic (microbial biomass carbon (Cmic, $\mathrm{mg} \mathrm{kg}^{-1}$ soil) and b) Cmic:Corg (microbial quotient, \%). Different letters indicate significant differences between the means of groups (Fisher's Least Significant Difference (LSD) test).

response and recovery after fire, except for PHP, which dropped according to time after fire and confirms previously obtained conclusions (López-Poma and Bautista, 2014; Certini, 2005; Knelman et al., 2015).

Successful plant regeneration has been related to availability of nutrients (Goberna et al., 2007), and promoted the microbial quotient in our study due to the increase in exchangeable cations, from ash deposition and decomposition, which was higher for moderate burn severity (Moya et al., 2018; Pausas et al., 2004). Corg was also dependent on plant recovery, especially to pine litter, which has been related to vegetation and climate effects more than to soil properties (Mastrolonardo et al., 2013).

In the studied semiarid stands, microbial activity after fire slowly recovered due to the low carbon mineralization rates and poor nutrient availability, which could increase vulnerability to more frequent and severe disturbances (Hinojosa et al., 2016). Soil extracellular acid phosphatase activity reduced according to higher burn severity, which has been related to fire damage and soil characteristics (Busse et al., 2005; Moya et al., 2018).

The activities of $\beta$-glucosidase, urease and dehydrogenase were enhanced according to time after fire. In closer areas, high burn severity promoted $\mathrm{P}$ and UR, but reduced GLU, with prefire values recovering in the mid-term (Moya et al., 2018; López-Poma and Bautista, 2014; Pizarro-Tobías et al., 2015). Acid phosphatase, produced mostly by plants, reduced according to time after fire, at least over the first 5 postfire years. After fire, available P usually increases due to the combustion of the organic part of fuel load and the deposition of ashes (MataixSolera, 1999), which was enhanced with high burn severity where the large amount of available P inhibited PHP (Pereira et al., 2018). This could be due to the combined effect of ephemeral higher inorganic $\mathrm{P}$ availability (due to a high surface temperature during fire) and the postfire drought decreasing microbial activity shortly after being consumed (Neary et al., 1999; Muñoz-Rojas et al., 2016). This is a key point related to burn severity and post-fire management, mainly in semiarid stands with frequent droughts where $\mathrm{P}$ availability is a limiting factor for Mediterranean ecosystems, especially for Aleppo pine recruitment (Ayari and Khouja, 2014; Sardans and Peñuelas, 2004).


Fig. 4. Significant differences in the post-fire enzymatic activities of soil 3 and 5 years after), depending on burn severity (unburned, low-moderate (LOW-MID) and moderate-high burn severity (MID-HIGH)). a) GLU ( $\beta$-glucosidase activity, $\mu$ mol PNP $\mathrm{g}^{-1} \mathrm{~h}^{-1}$ ); b) UR (urease activity, $\mu \mathrm{mol} \mathrm{NH}_{4}^{+} \mathrm{g}^{-1} \mathrm{~h}^{-1}$ ); c) PHP (phosphatase, $\mu \mathrm{mol}$ PNP $\mathrm{g}^{-1} \mathrm{~h}^{-1}$ ). Letters indicate the significant differences between the means of groups (Fisher's Least Significant Difference (LSD) test).

Burn severity negatively impacts the soil-plant system and increased the immaturity risk period in Aleppo pine stands to 21 years after fire in semiarid areas (Moya et al., 2018). Preventive methods to reduce forest fuel accumulation should be a critical and key point in forest management plans, especially in fire-prone landscapes, and also in dry or semiarid areas of the Mediterranean Basin (Hedo et al., 2015). Mechanical tools and prescribed burning have been implemented as land management tools to reduce fuel loads, but both can affect soil quality and plant communities (Francos et al., 2018; Plaza-Álvarez et al., 2017; Espinosa et al., 2018; Sagra et al., 2017). Post-fire restoration management should consider promoting plant diversity and the presence of resprouters, but also no intervention as an option to prevent, mitigate and reduce soil degradation (Pereira et al., 2018).

\section{Conclusions}

Our research concludes that in Mediterranean fire-prone Aleppo pine stands, different burn severities affect early plant community recovery patterns, linked to time after disturbance and the activity of soil extracellular enzymes. Fire effects followed different trends depending on burn severity which can be characterized by the alteration of soil microbial parameters, although impact was diluted with time in low burn severity. Also, burn severity induced differences in nutrient availability (mainly Phosphorus) and microbial activity varied probably due to lower ash incorporation into the soil. Also, variations in Cmic, 


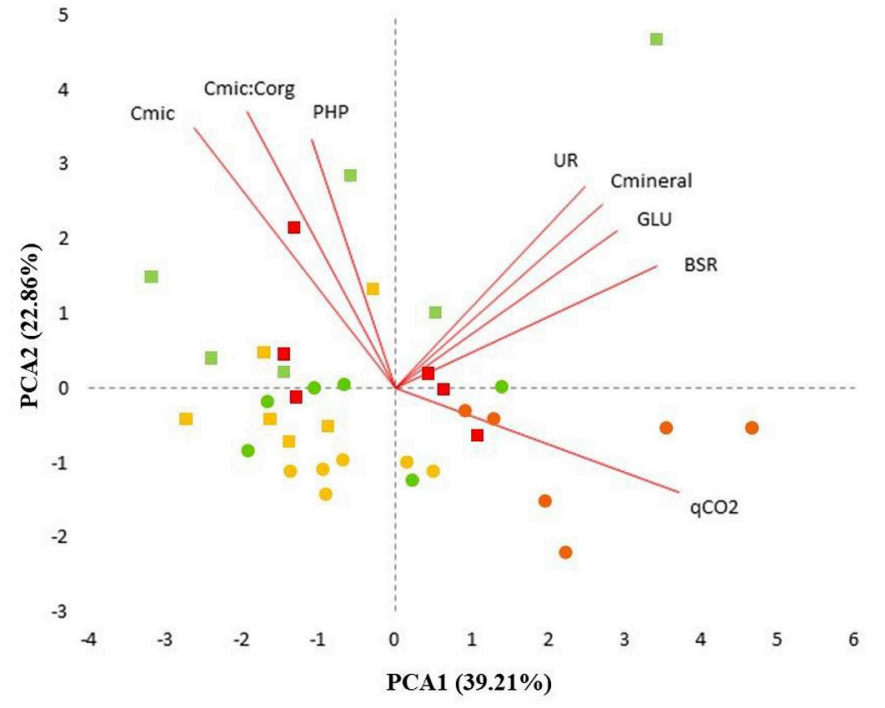

Fig. 5. The principal component analysis (PCA) diagram for the studied variables: basal soil respiration (BSR), the microbial biomass carbon ( $\mathrm{Cmic}$ ), the carbon mineralization coefficient (Cmineral), the metabolic quotient (qCO2), the microbial quotient (Cmic:Corg), urease (UR), phosphatase (PHP) and $\beta$ glucosidase (GLU). Dots represent the standardized values 3 (squares) and 5 (circles) years after a wildfire event colored in green (unburned), orange (lowmoderate burn severity), and red (moderate-high burn severity). PCA1: ecosystem response to burn severity; PCA2: ecosystem response to time after fire. (For interpretation of the references to colour in this figure legend, the reader is referred to the Web version of this article.)

Corg and Cmic, Corg ratio evidenced the damage produced by higher fire severity that remained five years after fire.

This knowledge could prove to be an effective tool to be included in adaptive forest management and wildfire prevention plans to conserve and restore landscape heterogeneity, and to conserve plant and soil biodiversity. This aspect is crucial in arid and semiarid regions with fire-prone habitats and vulnerable biological soil stability because undesirable intervention tools could degrade them. Thus, post-fire management should consider "no intervention" as a useful tool to mitigate the negative effects related to high burn severity on soil properties and nutrient cycles. In addition, this tool should include a monitoring and evaluation framework to quantify success rates in mitigating loss of ecosystem services and improving resilience, vulnerability and resilience.

According to our results, forest protection against fire should include not only fire prevention but, in case of new wildfires, to ensure patches burned with low severity to promote natural recovery in the short-term after fire.

Therefore, adaptive forest management should include tools to reduce burn severity and recurrence, such as prescribed fires and proper rehabilitation after wildfires, mainly in areas at high desertification risk.

\section{Acknowledgments}

We wish to thank the Regional Government of Castilla-La Mancha (Junta de Comunidades de Castilla-La Mancha) for help and field support, and Helen Warburton for her professional English editing and suggestions. This study was supported by a research award provided by the Instituto Estudios Albacetenses (IEA2016-Daniel Moya) and funds provided to the Forest Ecology Research Group by the University Castilla-La Mancha. The authors also thank the Spanish Institute for Agricultural and Food Research and Technology (INIA) for the funding awarded through National Research Projects GEPRIF (RTA2014-00011C06), POSTFIRE_CARE (CGL2016-75178-C2-1-R) financed by the
Spanish Research Agency (AIE), and the European Union for European Funding for Regional Development (FEDER).

\section{Appendix A. Supplementary data}

Supplementary data associated with this article can be found, in the online version, at https://doi.org/10.1016/j.jenvman.2019.01.029.

\section{References}

Alloza, J.A., García, S., Gimeno, T., Baeza, M.J., Vallejo, V.R., 2014. Guía técnica para la gestión de montes quemados. Ministerio de Agricultura, Alimentación y Medio Ambiente, pp. 188.

Andrés Abellan, M., Wic Baena, C., García Morote, F.A., Picazo Cordoba, M.I., Candel Pérez, D., Lucas-Borja, M.E., 2011. Influence of the soil storage method on soil enzymatic activities. For. Syst. 20 (3), 379-388.

Ayari, A., Khouja, M.L., 2014. Ecophysiological variables influencing Aleppo pine seed and cone production: a review. Tree Physiol. 34 (4), 426-437.

Bárcenas-Moreno, G., García-Orenes, F., Mataix-Solera, J., Mataix-Beneyto, J., 2016. Plant community influence on soil microbial response after a wildfire in Sierra Nevada National Park (Spain). Sci. Total Environ. 573, 1265-1274.

Bento-Gonçalves, A., Vieira, A., Úbeda, X., Martin, D., 2012. Fire and soils: key concepts and recent advances. Geoderma 191, 3-13.

Bond, W.J., Keeley, J.E., 2005. Fire as a global 'herbivore': the ecology and evolution of flammable ecosystems. Trends Ecol. Evol. 20, 387-394.

Bremmer, J.M., Mulvaney, C.S., 1982. Nitrogen total. In: Page, A.L., Miller, R.H., Keeney, D.R. (Eds.), Methods of Soil Analysis. Part 2. Chemical and Microbiological Properties. Soil Science Society of America and American Society of Agronomy, Madison, WI, pp. 595-624.

Broncano, M.J., Retana, J., 2004. Topography and forest composition affecting the variability in fire severity and post-fire regeneration occurring after a large fire in Mediterranean Basin. Int. J. Wildland Fire 13, 209-216.

Busse, M.D., Hubbert, K.R., Fiddler, G.O., Shestak, C.J., Powers, R.F., 2005. Lethal soil temperatures during burning of masticated forest residues. Int. J. Wildland Fire 14, $267-276$.

Certini, G., 2005. Effects of fire on properties of forest soils: a review. Oecol 143, 1-10.

DeBano, L.F., Neary, D.G., Ffolliott, P.F., 1998. Fire's Effects on Ecosystems. John Wiley \& Sons, New York, NY, pp. 331

Diaz-Delgado, R., Lloret, F., Pons, X., 2003. Influence of fire severity on plant regeneration through remote sensing imagery. Int. J. Rem. Sens. 24, 1751-1763.

Doblas-Miranda, E., Martínez-Vilalta, J., Lloret, F., Álvarez, A., Ávila, A., Bonet, F.J., Brotons, L., Castro, J., Curiel Yuste, J., Díaz, M., Ferrandis, P., García-Hurtado, E., Iriondo, J.M., Keenan, T.F., Latron, J., Llusià, J., Loepfe, L., Mayol, M., Moré, G., Moya, D., Peñuelas, J., Pons, X., Poyatos, R., Sardans, J., Sus, O., Vallejo, V.R., Vayreda, J., Retana, J., 2015. Reassessing global change research priorities in Mediterranean terrestrial ecosystems: how far have we come and where do we go from here? Glob. Ecol. Biogeogr. 24, 25-43.

Doblas-Miranda, E., Alonso, R., Arnan, X., Bermejo, V., Brotons, L., de las Heras, J. Estiarte, M., Hódar, J.A., Llorens, P., Lloret, F., López-Serrano, F.R., Martínez-Vilalta, J., Moya, D., Peñuelas, J., Pino, J., Rodrigo, A., Roura-Pascual, N., Valladares, F., Vilà, M., Zamora, R., Retana, J., 2017. A review of the combination among global change factors in forests, shrublands and pastures of the Mediterranean Region: beyond drought effects. Global Planet. Change 148, 42-54.

Egler, F.E., 1954. Vegetation science concepts. I. Initial floristic composition-a factor in old-field vegetation development. Vegetatio 4, 412-418.

Eugenio, M., Lloret, F., 2004. Fire recurrence effects on the structure and composition of Mediterranean Pinus halepensis communities in Catalonia (northeast Iberian Peninsula). Ecoscience 11, 446-454.

Espinosa, J., Madrigal, J., De La Cruz, A.C., Guijarro, M., Jimenez, E., Hernando, C., 2018. Short-term effects of prescribed burning on litterfall biomass in mixed stands of Pinus nigra and Pinus pinaster and pure stands of Pinus nigra in the Cuenca Mountains (Central-Eastern Spain). Sci. Total Environ. 618, 941-951.

Francos, M., Pereira, P., Mataix-Solera, J., Arcenegui, V., Alcañiz, M., Úbeda, X., 2018. How clear-cutting affects fire severity and soil properties in a Mediterranean ecosystem. J. Environ. Manag. 206, 625-632.

García-Morote, F.A., Martínez-García, E., Andrés-Abellán, M., Caballero, E.R., Miettinen, H., López-Serrano, F.R., 2017. Direct seeding of Pinus halepensis Mill. For recovery of burned semi-arid forests: implications for post-fire management for improving natural regeneration. Forests 8, 353.

Goberna, M., Pascual, J.A., García, C., Sanchez, J., 2007. Do plant clumps constitute microbial hotspots in semiarid Mediterranean patchy landscapes? Soil Biol. Biochem. 39 (5), 1047-1054.

Gómez-Sánchez, E., de las Heras, J., Lucas-Borja, M., Moya, D., 2017. Assessing fire severity in semi-arid environments: application in Donceles 2012 wildfire (SE Spain). Revista Teledetección 49, 103-113.

González-De Vega, S., de las Heras, J., Moya, D., 2016. Resilience of Mediterranean terrestrial ecosystems and fire severity in semiarid areas: responses of Aleppo pine forests in the short, mid and long term. Sci. Total Environ. 573, 1171-1177.

González-De Vega, S., de las Heras, J., Moya, D., 2018. Post-fire regeneration and diversity response to burn severity in Pinus halepensis Mill. Forests. Forests 9, 299.

Hedo, J., Lucas-Borja, M.E., Wic, B., Andrés Abellán, M., De las Heras, J., 2015. Experimental site and season over-control the effect of Pinus halepensis in microbial properties of soil under semiarid and dry conditions. J. Arid Environ. 116, 44-52. 
Hinojosa, M.B., Parra, A., Laudicina, V.L., Moreno, J.M., 2016. Post-fire soil functionality and microbial community structure in a Mediterranean shrubland subjected to experimental drought. Sci. Total Environ. 573, 1178-1189.

Keeley, J.E., 2009. Fire intensity, fire severity and burn severity: a brief review and suggested usage. Int. J. Wildland Fire 18, 116-126.

Keeley, J.E., Bond, W.J., Bradstock, R.A., Pausas, J.G., Rundel, P.W., 2012. Fire in Mediterranean Ecosystems: Ecology, Evolution and Management. Cambridge University Press, Cambridge.

Key, C.H., Benson, N.C., 2006. Landscape assessment (LA). In: Lutes, D.C., Keane, R.E., Caratti, J.F., Key, C.H., Benson, N.C., Sutherland, S., Gangi, L. (Eds.), FIREMON: Fire Effects Monitoring and Inventory System GTR-RMRS-164. U.S. Department of Agriculture, Forest Service, Rocky Mountain Research Station, Fort Collins, CO, pp. 55.

Kottek, M., Grieser, J., Beck, C., Rudolf, B., Rubel, F., 2006. World map of the KöppenGeiger climate classification. Meteorol. Z. 15, 259-263.

Knelman, J.E, Graham, E.B., Trahan, N.A., Schmidt, S.K., Nemergut, D.R., 2015, Fire severity shapes plant colonization effects on bacterial community structure, microbial biomass, and soil enzyme activity in secondary succession of a burned forest. Soil Biol. Biochem. 90, 161-168.

Liu, Z., 2016. Effects of climate and fire on short-term vegetation recovery in the boreal larch forests of Northeastern China. Sci. Rep. 6, 37572.

López-Poma, R., Bautista, S., 2014. Plant regeneration functional groups modulate the response to fire of soil enzyme activities in a Mediterranean shrubland. Soil Biol. Biochem. 79, 5-13.

Maia, P., Pausas, J.G., Arcenegui, V., Guerrero, C., Pérez-Bejarano, A., Mataix-Solera, J., Varela, M.E.T., Fernandes, I., Pedrosa, E.T., Keizer, J.J., 2012. Wildfire effects on the soil seed bank of a maritime pine stand-The importance of fire severity. Geoderma $191,80-88$.

Mastrolonardo, G., Certini, G., Krebs, R., Forte, C., Egli, M., 2013. Effects of fire on soil organic matter quality along an altitudinal sequence on Mt. Etna, Sicily. Catena 110, 133-145.

Mataix-Solera, J., 1999. Alteraciones físicas, químicas y biológicas en suelos afectados por incendios forestales. Contribución a su conservación y regeneración. PhD Thesis. Facultad de Ciencias. Universidad de Alicante, pp. 330.

Mataix-Solera, J., Guerrero, C., García-Orenes, F., Bárcenas-Moreno, G., Torres, P., 2009. Forest fire effects on soil microbiology. In: Cerdá, A., Robichaud, P.R. (Eds.), Fire Effects on Soil and Restoration Strategies. Science publishers, Endfield, pp. 133-175.

Mataix-Solera, J., Cerda, A., Arcenegui, V., Jordan, A., Zavala, L.M., 2011. Fire effects on soil aggregation. Earth Sci. Rev. 109, 44-60.

Miller, J.D., Thode, A.E., 2007. Quantifying burn severity in a heterogeneous landscape with a relative version of the delta Normalized Burn Ratio (dNBR). Rem. Sens. Environ. 109 (1), 66-80. https://doi.org/10.1016/j.rse.2006.12.006.

Moreira, F., Arianoustou, M., Vallejo, V.R., De las Heras, J., Corona, P., Xanthopoulos, G., Fernandes, P., Papageorgiou, K., 2012. Setting the scene for post-fire management. In: Moreira, F., Arianoustou, M., Corona, P., De Las Heras, J. (Eds.), Post-fire Management and Restoration of Southern European Forests. Springer, Dordrecht, The Netherlands, pp. 1-20.

Morugán-Coronado, A., García-Orenes, F., Cerdà, A., 2015. Changes in soil microbial activity and physicochemical properties in agricultural soils in Eastern Spain. Span. J. Soil Sci. 5 (3), 201-213.

Moya, D., González-De Vega, S., García-Orenes, F., Morugán-Coronado, A., Arcenegui, V., Mataix-Solera, J., Lucas-Borja, M.E., de las Heras, J., 2018. Temporal characterisation of soil-plant natural recovery related to fire severity in burned Pinus halepensis Mill. forests. Sci. Total Environ. 640-641, 42-51.

Moya, D., de las Heras, J., López-Serrano, F.R., Ferrandis, P., 2015. Post-Fire seedling recruitment and morpho-ecophysiological responses to induced drought and salvage logging in Pinus halepensis Mill. stands. Forests 6 (6), 1858-1877.

Moya, D., De las Heras, J., Lopez-Serrano, F.R., Leone, V., 2008. Optimal intensity and age of management in young Aleppo pine stands for post-fire resilience. For. Ecol. Manag. 255, 3270-3280.

Muñoz-Rojas, M., Erickson, T.E., Martini, D., Dixon, K.W., Merrit, D.J., 2016. Soil physicochemical and microbiological indicators of short, medium and long term post-fire recovery in semi-arid ecosystems. Ecol. Indicat. 63, 14-22.

Neary, D.G., Klopatek, C.C., DeBano, L.F., Ffolliott, P.F., 1999. Fire effects on belowground sustainability: a review and synthesis. For. Ecol. Manag. 122, 51-71.

Nelson, D.W., Sommers, L.E., 1982. Total carbon, organic carbon and organic matter. In: Page, A.L., Miller, R.H., Keeney, D.R. (Eds.), Methods of Soil Analysis. Part 2. Chemical and Microbiological Properties. Soil Science Society of America and
American Society of Agronomy, Madison, WI, pp. 539-579.

Olsen, S.R., Sommers, L.E., 1982. Phosphorus. In: Page, A.L., Miller, R.H., Keeney, D.R. (Eds.), Methods of Soil Analysis. Part 2. Chemical and Microbiological Properties. Soil Science Society of America and American Society of Agronomy, Madison, WI, pp. 403-430.

Pausas, J.G., Blade, C., Valdecantos, A., Seva, J.P., Fuentes, D., Alloza, J.A., Vilagrosa, A. Bautista, S., Cortina, J., Vallejo, R., 2004. Pines and oaks in the restoration of Mediterranean landscapes of Spain: new perspectives for an old practice - a review. Plant Ecol. 171, 209-220.

Pausas, J.G., Keeley, J.E., 2014. Evolutionary ecology of resprouting and seeding in fireprone ecosystems. New Phytol. 204, 55-65.

Pereira, P., Francos, M., Brevik, E.C., Ubeda, X., Bogunovic, I., 2018. Post-fire soil management. Curr. Opin. Environ. Sci. Health 5, 26-32.

Pizarro-Tobías, P., Fernández, M., Niqui, J.L., Solano, J., Duque, E., Ramos, J.-L., Roca, A., 2015. Restoration of a Mediterranean forest after a fire: bioremediation and rhizoremediation field-scale trial. Microb. Biotechnol. 8 (1), 77-92.

Plaza-Álvarez, P.A., Lucas-Borja, M.E., Sagra, J., Moya, D., Fontúrbel, T., de las Heras, J., 2017. Soil respiration changes after prescribed fires in Spanish black pine (Pinus nigra arn. ssp. salzmannii) monospecific and mixed forest stands. Forests 8, 248.

Quezel, P., 2000. Taxonomy and biogeography of Mediterranean pines (Pinus halepensis and P. brutia). In: Néeman, G., Trabaud, L. (Eds.), Ecology, Biogeography and Management of Pinus halepensis and P. Brutia Forest Ecosystems in the Mediterranean Basin. Backhuys publishers, Leiden, pp. 1-12.

Rivas-Martínez, S., 1982. Estage bioclimatiques, secteurs chorologiques et série de vegetation de l’Espagne méditerranéenne. Ecol. Mediterr. 8, 275-288.

Ryan, K., Noste, N., Lotan, J.E., et al., 1985. Evaluating prescribed fires. In: Proceedings Symposium and Workshop on Wilderness Fire. USDA Forest Service Intermountain Forest and Range Experiment Station, General Technical Report INT 182, pp. 230-238.

Sagra, J., Moya, D., Plaza-Álvarez, P.A., Lucas-Borja, M.E., Alfaro-Sánchez, R., De Las Heras, J., Ferrandis, P., 2017. Predation on early recruitment in mediterranean forests after prescribed fires. Forests 8, 243.

San-Miguel-Ayanz, J., Rodrigues, M., Santos de Oliveira, S., Kemper Pacheco, C., Moreira, F., Duguy, B., Camia, A., 2012. Land cover change and fire regime in the European Mediterranean region. In: In: Moreira, F., Arianoustsou, M., Corona, P., de las Heras, J. (Eds.), Post-Fire Management and Restoration of Southern European ForestsManaging Forest Ecosystems, vol. 24. pp. 21-43.

Santana, V.M., Alday, J.G., Baeza, M.J., 2014. Effects of fire regime shift in Mediterranean Basin ecosystems: changes in soil seed bank composition among functional types. Plant Ecol. 215 (5), 555-566.

Sardans, J., Peñuelas, J., 2004. Increasing drought decreases phosphorus availability in an evergreen Mediterranean forest. Plant Soil 267, 367-377.

Soil Survey Staff, 2014. Keys to Soil Taxonomy, twelfth ed. USDA-Natural Resources Conservation Service, Washington, DC.

Soler, M., Úbeda, X., 2018. Evaluation of fire severity via analysis of photosynthetic pigments: oak, eucalyptus and cork oak leaves in a Mediterranean forest. J. Environ. Manag. 206, 65-68.

Tabatabai, M.A., 1994. Enzymes. In: Weaver, R.W., Angle, J.S., Bottomley, P.S. (Eds.), Methods of Soil Analysis. Part 2. Soil Science Society of America and American Society of Agronomy, Madison, WI, pp. 755-833.

Tessler, N., Sapir, Y., Wittenberg, L., Greenbaum, N., 2016. Recovery of mediterranean vegetation after recurrent forest fires: insight from the 2010 forest fire on mount Carmel, Israel. Land Degrad. Dev. 27, 1424-1431.

Trabaud, L., 2000. Post-fire regeneration of Pinus halepensis forests in the west mediterranean. In: Neeman, G., Trabau, L. (Eds.), Ecology, Biogeography and Management of Pinus Halepensis and Pinus Brutia Forest Ecosystems in the Mediterranean Basin. Backhuys, Leiden, The Netherlands, pp. 257-268.

Úbeda, X., Outeiro, L.R., 2009. Physical and chemical effects of fire on soil. In: Cerdá, A., Robichaud, P.R. (Eds.), Fire Effects on Soil and Restoration Strategies. Science publishers, Endfield, pp. 105-132.

Vance, E.D., Brookes, P.C., Jenkinson, D.S., 1987. An extraction method for measuring soil microbial biomass C. Soil Biol. Biochem. 19, 703-707.

Vega, J.A., Fontúrbel, T., Merino, A., Fernández, C., Ferreiro, A., Jiménez, E., 2013. Testing the ability of visual indicators of soil burn severity to reflect changes in soil chemical and microbial properties in pine forests and shrubland. Plant Soil 369, $73-91$.

Zavala, L.M., de Celis, R., Jordán, A., 2014. How wildfires affect soil properties. A brief review. Cuadernos Investigación Geográfica 40 (2), 311-331. 